\title{
Flexible viologen cyclophanes: odd/even effects on intramolecular interactions
}

\author{
Mathilde Berville, ${ }^{[a]}$ Sylvie Choua ${ }^{[b]}$ Christophe Gourlaouen, ${ }^{\left[{ }^{[c]}\right.}$ Corinne Boudon, ${ }^{[d]}$ Laurent Ruhlmann, ${ }^{[d]}$ \\ Corinne Bailly, ${ }^{[\mathrm{e}]}$ Saioa Cobo, ${ }^{[\mathrm{f}]}$ Eric Saint-Aman, ${ }^{[\mathrm{f}]}$ Jennifer Wytko*[a] and Jean Weiss, ${ }^{*[\mathrm{a}]}$
}

\begin{abstract}
The ability of three bis-viologen cyclophanes to act as redox-triggered contractile switches was investigated. Odd/even effects in the formation of cyclic bis-viologens were circumvented by the use of a Zincke salt intermediate and a tetrathiafulvalene template to prepare a flexible cyclophane with hexyl linkers. Comparative spectro-electrochemical studies of this macrocycle with two other pentyl- or heptyl-linked cyclic bis-viologens showed that the development of intramolecular interactions in aqueous solution depended on the length of the bridges. This dependence was confirmed by EPR and DFT studies of the magnetic coupling in the di(radical cation) species. The anti-ferromagnetic or ferromagnetic nature of the coupling depended respectively on the odd or even number of methylene units in the spacer.
\end{abstract}

\section{Introduction}

Stimuli-responsive molecular species are of primary importance in modern host-guest chemistry and the era of molecular machines. ${ }^{[1]}$ The motion of these scaffolds stems from geometrical and conformational changes induced by light, $\mathrm{pH}$ changes, redox reactions, ion exchange or guest binding. ${ }^{[1,2]}$ In the more restricted field of directional molecular motions, the

[a] Dr. M. Berville, Dr. J. A. Wytko, Dr. J. Weiss

Laboratoire de Chimie des Ligands à Architecture Contrôlée Institut de Chimie, UMR 7177 CNRS-Université de Strasbourg

4 rue Blaise Pascal, 67008 Strasbourg, France

E-mail: jwytko@unistra.fr; jweiss@unistra.fr

[b] Dr. S. Choua

Laboratoire de Propriétés Optiques et Magnétiques des

Architectures Moléculaires

Institut de Chimie, UMR 7177 CNRS-Université de Strasbourg

4 rue Blaise Pascal, 67008 Strasbourg, France

[c] Dr. C. Gourlaouen

Laboratoire de Chimie Quantique

Institut de Chimie, UMR 7177 CNRS-Université de Strasbourg

1 rue Blaise Pascal, 67008 Strasbourg, France

[d] Prof. C. Boudon, Prof. L. Ruhlmann

Laboratoire d'Electrochimie et Chimie Physique du Corps Solide Institut de Chimie, UMR 7177 CNRS-Université de Strasbourg

4 rue Blaise Pascal, 67008 Strasbourg, France

[e] Mrs. C. Bailly

Service de Cristallographie

GDS 3648 CNRS-Université de Strasbourg

1 rue Blaise Pascal, 67008 Strasbourg, France

[f] Dr. S. Cobo, Prof. E. Saint-Aman

Département de Chimie Moléculaire (UMR 5250), Laboratoire de Chimie Inorganique Rédox

Université Grenoble Alpes, 38000 Grenoble, France

Supporting information for this article, including binding titrations and fits, crystal packing, electrochemistry figures, EPR and DFT data, is given via a link at the end of the document. oxidation or reduction of a molecular component is an easily controlled trigger, both qualitatively and quantitatively. [3 ] Examples of redox-stimulated molecular motion include scissor${ }^{[4]}$ or tweezer-like ${ }^{[5]}$ movement, linear shuttling in rotaxanes, ${ }^{[1 d, 6,6]}$ as well as contraction and extension of molecular muscles built from rotaxanes. ${ }^{[8]}$ In macrocyclic structures, redox-triggered contraction driven by intramolecular $\pi$-dimerization has been described in scaffolds containing redox-active moieties such as tetrathiafulvalenes $(\mathrm{TTF})^{[5 d, 9]}$ oligothiophene ${ }^{[10]}$ or perylenes, ${ }^{[11]}$ linked by flexible spacers.

Among the numerous redox-active molecules, viologens have been selected for decades as building blocks with switchable properties due to their multiple and accessible redox states. In addition, viologen derivatives form $\pi$-dimers in their radical cation state at low temperature ${ }^{[12]}$ and in aqueous or confined media. ${ }^{[13]}$ In non-cyclic, covalently linked bis-viologens, $\pi$-dimerization is also possible when appropriate, flexible alkyl spacers are present in the architecture. ${ }^{[14]}$ However, macrocycles comprised of two viologen subunits rarely form intramolecular $\pi$-dimers. For Stoddart's rigid, macrocyclic "bluebox", i.e. cyclo(bis-paraquat- $p$-phenylene $)^{[15]}$ only intermolecular $\pi$-dimers have been observed in the solid state ${ }^{[16]}$ or in inclusion complexes with radical cation guests. ${ }^{[17]}$ This article describes solution studies of a series of new flexible "blue-box" analogs, or "flex-boxes" (Figure 1), in which the odd or even number of methylene groups in the alkyl chain linking the viologens contribute to the control of the intramolecular $\pi$-dimerization or similar electronic interactions.

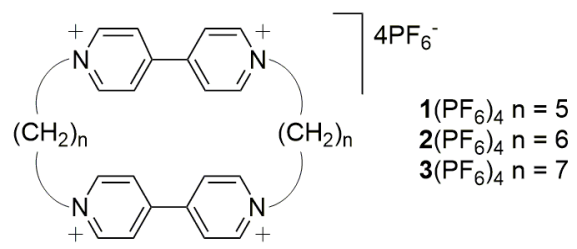

Figure 1. Bis(viologen) cyclophanes with alkyl linkers.

\section{Results and Discussion}

Recently, our group reported the synthesis of two bisviologen cyclophanes $\mathbf{1}\left(\mathrm{PF}_{6}\right)_{4}$ and $\mathbf{3}\left(\mathrm{PF}_{6}\right)_{4}$ with alkyl spacers and the modulation of their solid state host-guest properties upon reduction. ${ }^{[18]}$ Synthetic yields were low, unaffected by the use of templates and surprisingly sensitive to an odd or even number of carbon atoms in the intended alkyl linkers. Cyclophanes with an even number of carbons in the alkyl linkers were not produced by this method. An alternate synthetic approach employing the 
Zincke reaction ${ }^{[19,20]}$ was designed from the assumption that the use of an electron rich template would be most efficient if applied to the cyclization of a tetracationic bis-viologen clip $5^{4+}$ rather than to a partially quaternized bipyridine intermediate such as $4^{2+}$. TTF was selected as a possible template because it forms a green charge transfer complex with the larger $3\left(\mathrm{PF}_{6}\right)_{4}$ cyclophane. Despite the low binding constant $\left(\mathrm{K}_{\mathrm{a}}=21 \pm 1 \mathrm{M}^{-1}\right.$ in $\mathrm{MeCN}$, see $\mathrm{SI}$ ) of the latter with TTF, we reasoned that binding might be stronger with $2\left(\mathrm{PF}_{6}\right)_{4}$, which should have a smaller cavity than $3\left(\mathrm{PF}_{6}\right)_{4}$. To generate a bis-viologen clip, the hexyllinked bis(pyridinium-pyridine) ${ }^{[21]} \mathbf{4}^{2+}$ was treated with 2,4-dinitrochlorobenzene in refluxing MeCN (Scheme 1) to give the Zincke salt $5^{4+}$ in $81 \%$ yield. Further reaction of this salt with $1,6-$ hexanediamine in the presence of two equivalents of TTF afforded a green crude mixture. Excess TTF was used due to its low binding constant (vide infra). Removal of the TTF by liquid/liquid extraction, purification by column chromatography and anion exchange afforded the cyclophane $2\left(\mathrm{PF}_{6}\right)_{4}$ in $14 \%$ yield. When the last synthetic step was carried out in the absence of TTF, $2\left(\mathrm{PF}_{6}\right)_{4}$ was isolated in $1.5 \%$ yield. The corresponding chloride salt, $2 \mathrm{Cl}_{4}$ was prepared by anion exchange using $\mathrm{NEt}_{4} \mathrm{Cl}$. The chloride salts of $\mathbf{1}^{4+}$ and $3^{4+}$ were prepared in a similar fashion.

The emerald green color observed during the cyclization step in the presence of TTF suggested that the latter and the Zincke salt $5^{4+}$ might form a sandwich-like charge transfer complex that preoganizes the viologens for the cyclization. However, a UV-visible titration of $\mathbf{5}\left(\mathrm{PF}_{6}\right)_{4}$ with TTF in $\mathrm{MeCN} / \mathrm{EtOH}$ (3/1) demonstrated a negligible affinity (see SI) between these compounds. ${ }^{[22]} \mathrm{A}$ charge transfer band was also observed at $765 \mathrm{~nm}$ upon addition of TTF to $2\left(\mathrm{PF}_{6}\right)_{4}$ but the UVvisible titration showed a weak affinity of $2\left(\mathrm{PF}_{6}\right)_{4}$ for TTF $\left(\mathrm{K}_{\mathrm{a}}=\right.$ $104 \pm 2 \mathrm{M}^{-1}$ in MeCN) (see SI).
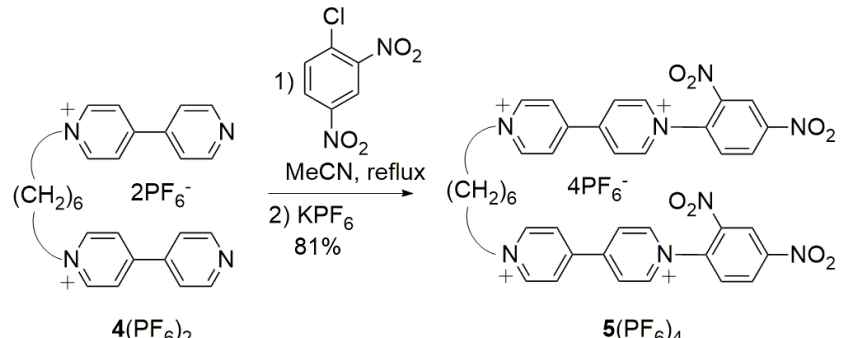

$$
4\left(\mathrm{PF}_{6}\right)_{2}
$$

$\mathbf{5}\left(\mathrm{PF}_{6}\right)_{4}$

1) $\mathrm{H}_{2} \mathrm{~N}-\left(\mathrm{CH}_{2}\right)_{6}-\mathrm{NH}_{2}$ TTF

$\mathrm{MeCN} / \mathrm{EtOH}, 12 \mathrm{~h}$

2) $\mathrm{NH}_{4} \mathrm{PF}_{6}$

$14 \%$

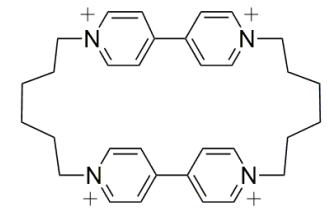

$\mathbf{2}\left(\mathrm{PF}_{6}\right)_{4}$

Scheme 1. Synthesis of cyclophane $2^{4+}$ with hexyl linkers.

Nonetheless, the yield of cyclization significantly improved in the presence of TTF. A tentative explanation probably resides in the multi-step character of the reaction of a Zincke salt with an amine. Within the numerous steps that are reversible, except for the final one, ${ }^{[23]}$ the stabilization of only one cyclic intermediate by the electron rich TTF might be sufficient to template the formation of $2\left(\mathrm{PF}_{6}\right)_{4}$. The preparation of cyclophanes $1^{4+}$ and $3^{4^{+}}$ via a Zincke intermediate was not tried for several reasons. First, a templated synthesis of $1^{4+}$ is highly unlikely because the macrocyclic cavity is too small to host a TTF guest, as shown by the absence of a charge transfer band during a titration of $1^{4+}$ with TTF (see ESI). Second, although the cavity of $3^{4+}$ is of adequate size to host TTF, ${ }^{[18]}$ the affinity of this host and guest in solution is probably too weak to effectively template the cyclization. Thus, we did not attempt to optimize this strategy because satisfactory quantities of $1^{4+}$ and $3^{4+}$ could be obtained in only two steps by the previously reported method. ${ }^{[18]}$ Nevertheless, the necessity to use the strategy in Scheme 1 rather than the previously reported method for the synthesis of the hexyl-linked macrocycle $2^{4+}$ suggests that conformational constraints imposed by the number of methylene groups of the spacer are a determining factor in the cyclization step. On several occasions, odd/even effects have also been observed in the synthesis of several other macrocycles containing alkyl spacers. ${ }^{[24]}$

Single crystals[ ${ }^{25]}$ of $\mathbf{2}\left(\mathrm{PF}_{6}\right)_{4}$ were obtained by slow diffusion of diisopropylether into a dilute $\mathrm{MeCN}$ solution of the cyclophane. In the solid state structure of $2^{4+}$ in Figure 2, the alkyl chains have a gauche conformation. To accommodate this conformation, a torsion angle of $27^{\circ}$ exists between the viologen units of the macrocycle. The pyridinium rings in each dicationic viologen are twisted with respect to each other, with a dihedral angle of $38^{\circ}$ that indicates a lack of conjugation. The macrocycle is $6.15 \AA$ high and $10.43 \AA$ wide. No intermolecular interactions are observed in the solid state, as shown by the offset arrangement of each macrocycle in the packing of $2^{4+}$ (see $\mathrm{SI}$ ).

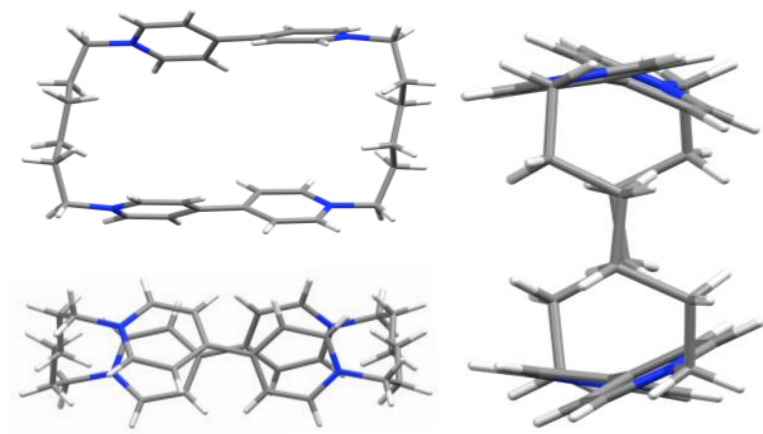

Figure 2. Solid state structure of $2\left(\mathrm{PF}_{6}\right)_{4}$ determined by $\mathrm{X}$-ray diffraction. Left: face and top view; Right: Side view. Anions $\left(\mathrm{PF}_{6}^{-}\right)$are omitted for clarity.

The ability of the cyclophanes $1 \mathrm{Cl}_{4}-3 \mathrm{Cl}_{4}$ to $\pi$-dimerize in water was investigated by electrochemistry and spectroelectrochemistry. To limit the possibility of intermolecular $\pi$ dimerization, these studies were carried out at concentrations $\leq 2 \times 10^{-4} \mathrm{M}$. This critical concentration was determined from spectro-electrochemical studies of the one-electron reduction of aqueous methylviologen $\left(\mathrm{MV}^{2+}\right)$ at $4 \times 10^{-4} \mathrm{M}$ (see SI).

Cyclic voltammetry (CV) from 0 to $-1.2 \mathrm{~V}$ vs $\mathrm{AgCl} / \mathrm{Ag}$ on either a platinum or glassy carbon (GC) electrode clearly indicated adsorption of the neutral species (i.e. the fully reduced 
Table 1. Electrochemical data of derivatives observed by cyclic voltammetry $(\mathrm{CV})$ and rotating disk voltammetry (RDV) in $\mathrm{H}_{2} \mathrm{O}+0.1 \mathrm{M}$ $\mathrm{KCl}$. All potentials are given versus $\mathrm{AgCl} / \mathrm{Ag}$, used as standard, and are uncorrected from ohmic drop.

\begin{tabular}{|c|c|c|c|c|c|}
\hline & $E^{\circ}(V)^{[a]}$ & $\underset{[\mathrm{b}]}{\Delta \mathrm{E}_{\mathrm{p}}(\mathrm{mV})}$ & $E_{p}(V)^{[c]}$ & $\begin{array}{l}E_{1 / 2} \\
(V)\end{array}$ & slope $(m V)^{[d]}$ \\
\hline & $\mathrm{Pt}$ & & & Pt & \\
\hline \multirow[t]{6}{*}{$\mathrm{MVCl}_{2}$} & -0.65 & 55 & & -0.66 & 60 \\
\hline & -0.98 & 50 & & -0.99 & 60 \\
\hline & $G C$ & & & $G C$ & \\
\hline & -0.63 & 55 & & -0.65 & 60 \\
\hline & -0.99 & 50 & & -0.99 & 60 \\
\hline & $\mathrm{Pt}$ & & & $\mathrm{Pt}$ & \\
\hline \multirow[t]{6}{*}{$1 \mathrm{Cl}_{4}$} & -0.49 & 50 & & -0.52 & 80 \\
\hline & -0.92 & 56 & & -0.93 & 40 \\
\hline & $G C$ & & & $G C$ & \\
\hline & -0.51 & 65 & & -0.52 & 82 \\
\hline & -0.83 & 90 & & -0.93 & 30 \\
\hline & $\mathrm{Pt}$ & & & $\mathrm{Pt}$ & \\
\hline \multirow[t]{6}{*}{$2 \mathrm{Cl}_{4}$} & -0.55 & 56 & & -0.56 & 60 \\
\hline & -0.83 & 124 & & -0.87 & 30 \\
\hline & $G C$ & & & $G C$ & \\
\hline & -0.55 & 60 & & -0.57 & 75 \\
\hline & -0.83 & 124 & & -0.88 & 30 \\
\hline & Pt & & $\mathrm{Pt}$ & & \\
\hline \multirow[t]{7}{*}{$3 \mathrm{Cl}_{4}$} & -0.57 & 90 & & & \\
\hline & & & $E_{p c}:-0.91^{*}$ & & \\
\hline & & & $\mathrm{E}_{\mathrm{pa}}:-0.70^{*}$ & {$[\mathrm{e}]$} & \\
\hline & $G C$ & & $G C$ & & \\
\hline & -0.56 & 110 & & & \\
\hline & & & $E_{p c}:-0.93^{+}$ & [e] & \\
\hline & & & $\mathrm{E}_{\mathrm{pa}}:-0.69^{\star}$ & & \\
\hline
\end{tabular}

[a] $E^{\circ}=\left(E_{\mathrm{pc}}+E_{\mathrm{pa}}\right) / 2$, where $E_{\mathrm{pc}}$ and $E_{\mathrm{pa}}$ correspond to the cathodic and anodic peak potentials, respectively; [b] $\Delta E_{\mathrm{p}}=\mathrm{E}_{\mathrm{pa}}-\mathrm{E}_{\mathrm{pc}} ;$ [c] $E_{\mathrm{p}}=$ irreversible peak potential; [d] logarithmic analysis of the wave obtained by plotting $E$ versus $\log \left[I /\left(I_{\text {lim }}-\Lambda\right)\right]$; [e] unresolved signals. ${ }^{*} E_{\mathrm{pc}}$ and $E_{\mathrm{pa}}$ correspond to the cathodic and anodic peak potentials respectively with $\Delta E_{\mathrm{p}}=210 \mathrm{mV}(\mathrm{Pt})$ and $240 \mathrm{mV}(\mathrm{GC})$.

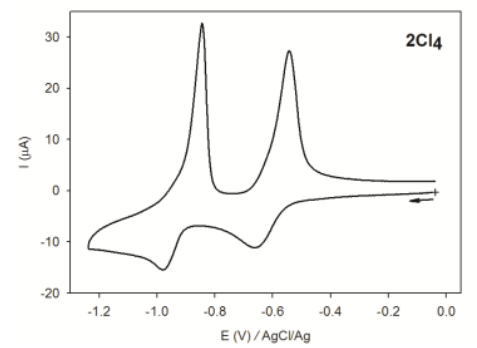

Figure 3. Cyclic voltammogram of $2 \mathrm{Cl}_{4}$ in water $+0.1 \mathrm{M} \mathrm{KCl}$;.working electrode: glassy carbon disk (GC), auxiliary electrode: Pt wire, pseudo reference electrode: Pt wire.

cyclophane) at the electrode. However, for $1 \mathrm{Cl}_{4}$ and $2 \mathrm{Cl}_{4}$, the first two-electron reduction leading to the di(radical cation) and the subsequent reoxidation were reversible on both glassy carbon and platinum electrodes (see Table 1 for redox potentials and $\mathrm{SI}$ ). Figure 3 shows a cyclic voltammogram of $2 \mathrm{Cl}_{4}$, which is
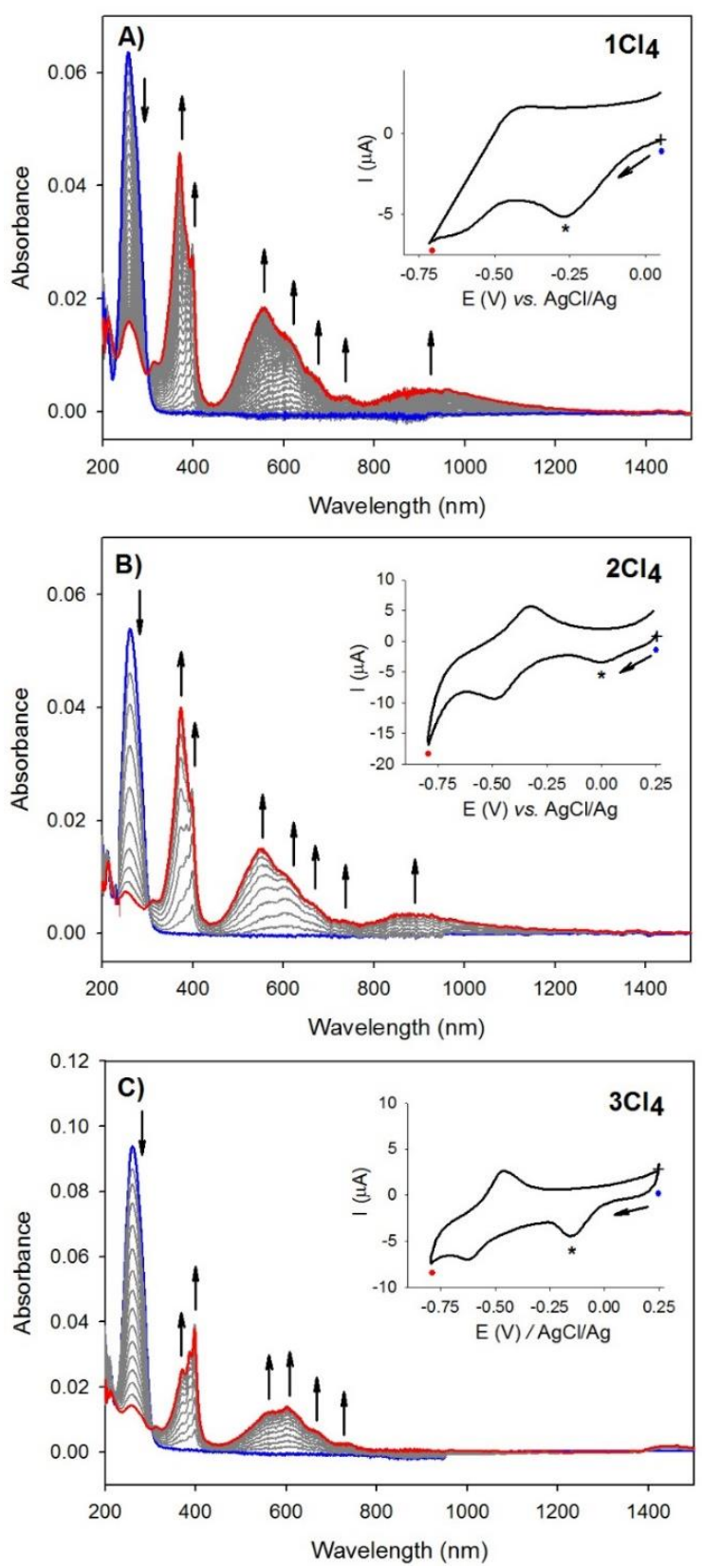

Figure 4. UV-visible-NIR monitoring of $\pi$-dimer formation during scans from 0.25 to $-0.80 \mathrm{~V}$ vs. $\mathrm{AgCl} / \mathrm{Ag}$ at $0.01 \mathrm{Vs}^{-1}$ for cyclophanes $\mathbf{1 C l}_{\mathbf{4}}, \mathbf{2} \mathbf{C l}_{4}$, and $\mathbf{3} \mathrm{Cl}_{4}$ in $\mathrm{H}_{2} \mathrm{O},[\mathrm{KCl}]=0.1 \mathrm{M}$, working electrode: $\mathrm{Pt}$ mini-grid, optical pathway $=0.1$ $\mathrm{cm}$.

similar to that of $1 \mathrm{Cl}_{4}$ (see $\mathrm{SI}$ ). For $3 \mathrm{Cl}_{4}$, the first reduction is quasi-reversible (see $\mathrm{SI}$ ). Thus, in the potential range from 0 to $-0.8 \mathrm{~V}$, spectro-electrochemical investigation of the di(radical cation) absorption properties in the near infrared (NIR) was possible for all three cyclophanes.

Again, all compounds were studied at a constant concentration of viologen units in solution with $\left[\mathrm{MV}^{2+}\right]=2 \times[(1-$ 3) $\mathrm{Cl}_{4}$ ] for comparison purposes. For $3 \mathrm{Cl}_{4}$, no NIR absorption was detected, indicating the absence of $\pi$-dimer for $3^{2(++)}$. For $1 \mathrm{Cl}_{4}$ 
and $2 \mathrm{Cl}_{4}$, while cycling from -0.25 to $-0.80 \mathrm{~V}$ at $0.01 \mathrm{Vs}^{-1}$ on an optically transparent $\mathrm{Pt}$ grid, the simultaneous recording of the UV-vis-NIR spectrum showed the growth of an absorption band at 878 and $900 \mathrm{~nm}$, respectively. These absorptions in the NIR region are typical of the formation of $\pi$-dimers ${ }^{[12 a, 26]}$ and of a multi-centered bonding orbital between the two viologens of each cyclophane. ${ }^{[27]}$

In the case of 3, the adsorption tendency at the mini Pt grid electrode was observed even at the first reduction step giving $3^{2(++)}$. Under the same conditions at a concentration of $4 \times 10^{-4} \mathrm{M}$ in $\mathrm{H}_{2} \mathrm{O}, \mathrm{MV}^{*+}$ shows only the first hints of intermolecular $\pi$-dimer formation (see $\mathrm{SI}$ ). However, the absence of an absorption band in the NIR for $3 \mathrm{Cl}_{4}$ indicates that intermolecular interactions are not present when the cyclophanes are studied at $2 \times 10^{-4} \mathrm{M}$. Thus, the observed NIR absorption in the di(radical cationic) species $\mathbf{1}^{2(+)}$ and $2^{2(+)}$ can be assigned to intramolecular electronic interactions resulting from a contraction of the cyclophane. These interactions do not occur in $3 \mathrm{Cl}_{4}$ because the seven-carbon chain between the bipyridinium moieties imposes a longer distance between the two radical cationic species. On the contrary, the pentyl and hexyl chains are sufficiently short to favor interactions between the two viologens in their radical cation state, leading to the formation of a $\pi$-dimer.

Distance is not the only relevant parameter in the efficiency of the $\pi$-dimer formation. Intuitively, if the distance between the viologen radical cations were the only factor modulating the redox-triggered $\pi$-dimer formation, a five-carbon linker would be expected to be more efficient than a six-carbon connection. Experimentally, several features of the spectroelectrochemical studies of $\mathbf{1 C l}_{4}$ suggest a less efficient production of $\pi$-dimer than in $2 \mathrm{Cl}_{4}$. In the smaller cyclophane, full reduction could not be achieved during simple scanning of the reduction potential. To observe the characteristic absorption band of the intramolecular $\pi$-dimer, it was necessary to either hold the reduction potential at $-0.75 \mathrm{~V}(\mathrm{AgCl} / \mathrm{Ag})$ or perform iterative cyclic voltammetry around the first reduction potential and monitor the 200-1400 nm region. On the contrary, with the hexyl chain of cyclophane $2 \mathrm{Cl}_{4}$, intramolecular $\pi$-dimer formation was very fast and the evolution of the corresponding absorption band was observed during the continuous potential scan.

These observations strongly suggest that establishing electronic interactions such as $\pi$-dimer formation between two covalently linked viologens is not exclusively controlled by the length of the linker but also by its conformational flexibility. An even number of carbon atoms seems more appropriate for bringing two viologen units "face-to-face" than an odd number, as emphasized by comparing the length of the spacers.

X-band EPR spectra of di(radical cation) species provided more detailed information about the electronic structures of the cyclophanes. At room temperature, the reduced species were generated by electrolysis in situ at $2 \times 10^{-4} \mathrm{M}$ in water to minimize intermolecular interactions. In the case of $3^{2(+)}$, only a very weak signal was recorded (see SI). The blue color characteristic of the di(radical cationic) species appeared mostly in the vicinity of the electrode, confirming the adsorption tendency already observed in the spectro-electrochemistry studies. However, a very well resolved EPR signal was observed for $\mathbf{2}^{2(\cdot+)}$, revealing an exchange interaction between two radicals in the limit of a strong exchange (see SI). The EPR spectrum (Figure 5) of this di(radical cation) fits perfectly with a two spin species, with hyperfine coupling constants (hfc) divided by two compared to that of the $\mathrm{MV}^{*+}$ reference compound under the same experimental conditions (see SI). The hfc of $\mathbf{2}^{2\left({ }^{(+)}\right)}$were assigned by analogy with those of the $\mathrm{MV}^{++}$radical cation. ${ }^{[28]}$ For $\mathbf{1}^{2(\cdot+)}$, a less resolved signal (see SI) did not allow measurement of the hyperfine coupling constants.

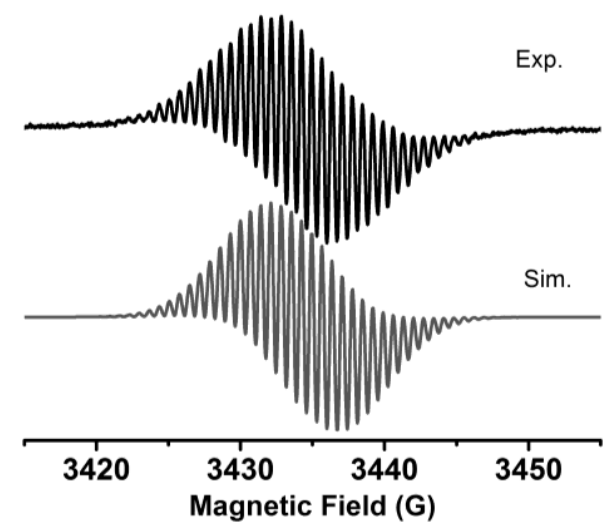

Figure 5. X-band EPR spectrum of $\mathbf{2}^{2(\cdot+)}$ generated by electrolysis in water $[\mathrm{KCl}]=0.1 \mathrm{M}$ at room temperature.

To determine the spin state of the molecules, a series of geometry optimization were undertaken, starting from the experimental crystal structure ${ }^{18}$ for $\mathbf{1}^{2(++)}$ and $3^{2(+)}$ (further denoted as $1^{2(++)}(R X 1), 1^{2(++)}(R X 2)$ and $\left.3^{2(++)}(R X)\right)$ and that of the $2^{2(+)}$ (further denoted as $\mathbf{2}^{2(\cdot)}(R X)$ ) molecule was optimized starting from the structure of $\mathbf{2}^{4+}$. For $\mathbf{1}^{2(+)}$, two structures are present in the crystal and were both studied. Due to the flexible nature of the alkyl linkers in the cyclophanes, the conformation adopted in the crystal structure may not be representative of those present in solution. Other arrangements of the side chains were optimized to investigate the role of the geometry on the spin state. The structures optimized from the X-ray data are hereafter designated as $\mathrm{RX}$ and the other constructed conformers as GA, GB, etc. The molecules were fully optimized with no symmetry in the closed shell singlet (CSS) and open shell triplet $(T)$ states. The energy of the open shell singlet state (OSS) was evaluated using a single point on the optimized triplet geometry (see details in ESI). The main results are summarized in Figure 6 and details concerning the geometry optimization are provided as supporting information.

For all structures, the unpaired electrons are, as expected, localized on the $\pi$ system of the viologen fragments (see ESI) with negligible contribution of the alkyl side chains. A second general observation is that the CSS state is never the ground state and is typically much higher in energy than the OSS and T states, particularly for the conformers of $3^{2(+)}$. Otherwise, the energy difference between OSS and T states strongly depends on the geometry. 


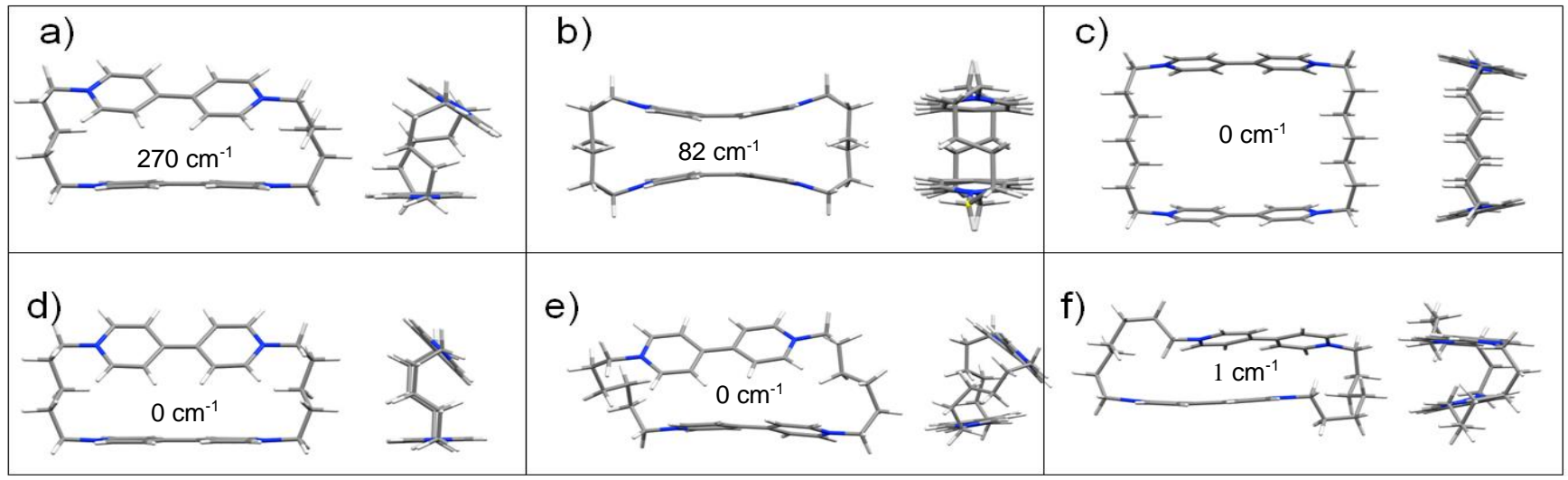

Figure 6. Optimized geometries of (a) $\mathbf{1}^{2(++)}(\mathrm{T})$, (b) $\mathbf{2}^{2(++)}(\mathrm{GB}, \mathrm{CSS}),(\mathrm{c}) \mathbf{3}^{2(+)}(\mathrm{RX}, \mathrm{T}),(\mathrm{d}) \mathbf{1}^{2(++)}(\mathrm{GA}, \mathrm{OSS}),(\mathrm{e}) \mathbf{2}^{2(++)}(\mathrm{GE}, \mathrm{OSS}),(\mathrm{f}) \mathbf{3}^{2(++)}(\mathrm{GA}, \mathrm{OSS})$,

For $\mathbf{1}^{2(++)}$, the most stable state is the OSS of $\mathbf{1}^{2(\cdot+)}(\mathrm{GA})$, although the triplet state of this optimized structure is close enough in energy $\left(270 \mathrm{~cm}^{-1}\right)$ to be thermally accessible (see Table S2); particularly at room temperature. By analogy with the solid state structure, an open shell singlet of $1^{2(++)}(\mathrm{RX} 2$, OSS) lies only $326 \mathrm{~cm}^{-1}$ higher in energy than $\mathbf{1}^{2(\cdot+)}(\mathrm{GA}, \mathrm{OSS})$. In both structures the viologens are not parallel, their average planes exhibiting dihedral angles of $37^{\circ}\left(1^{2(*)}(\mathrm{GA}, \mathrm{OSS})\right)$ and $61^{\circ}$ $\left(1^{2(+)}(\mathrm{RX}, \mathrm{OSS})\right)$ with respect to one another. The two structures differ mainly by the orientation of one of the side chains (Figures $6 \mathrm{a}-\mathrm{d})$ and are probably in equilibrium in the solution. The closest carbon-carbon edge-to-edge distance is $3.6 \AA$ in both conformers illustrates the attempted development of electronic intramolecular interactions hampered by the distortion of the side-chains. The lowest energy conformer, $\mathbf{2}^{2(++)}(\mathrm{GE}, \mathrm{OSS})$ (Figure 6e), corresponds to an OSS. However, the triplet state of this same structure, $\mathbf{2}^{2(++)}(\mathrm{GE}, \mathrm{T})$ and the CCS state of a second optimized conformer, $\mathbf{2}^{2(+)}(\mathrm{GB}, \mathrm{CSS})$, are respectively only 77 $\mathrm{cm}^{-1}$ and $82 \mathrm{~cm}^{-1}$ above $2^{2(++)}(\mathrm{GE}, \mathrm{OSS})$. In $2^{2(+)}(\mathrm{GB}, \mathrm{CSS})$, the two viologens are almost perfectly superimposed (Figure $6 b$ ), which is not the case for the other structures. At the closest point, the carbon atoms of the two viologens are separated by $3.0 \AA$. The two viologen subunits in conformer $\mathbf{2}^{2(\cdot+)}(\mathrm{GE}, \mathrm{OSS})$ adopt a tilted geometry of their mean planes similar with a $55^{\circ}$ dihedral angle similar to that of $\mathbf{1}^{2(+)}\left(\mathrm{GA}\right.$, OSS) and $\mathbf{1}^{2(++)}(\mathrm{RX} 2, \mathrm{OSS})$. Within an energy range of $600 \mathrm{~cm}^{-1}$, at least four other possible conformers were identified for $\mathbf{2}^{2(+)}$ (see $\mathrm{ESI}$ ); therefore this molecule is significantly more flexible than $1^{2(\cdot+)}$. Due to such small energy differences, $\mathbf{2}^{2(+)}$ can thermally adopt many different conformations and spin states. The calculated OSS ground state of cyclophane $\mathbf{2}^{2(\cdot+)}$ fits well with the EPR data described above.

The results for $3^{2(+)}$ are completely different from those of the other two cyclophanes. For this compound, none of the calculated conformers are lower in energy than the crystal structure (see ESI). Only two conformers, $3^{2(\cdot+)}(\mathrm{GA}, \mathrm{T})$ (Figure $6 \mathrm{c})$ and $3^{2(+)}(\mathrm{GA}, \mathrm{OSS})$, are reasonably close in energy to the crystal structure. Furthermore, our calculations do not clearly indicate the spin state of the molecule because $3^{2(+)}(R X, T)$ and $3^{2(+*)}(\mathrm{RX}, \mathrm{OSS})$ are almost perfectly degenerate. In the latter, shown in Figure 6c, the nearly parallel viologens are within the range of van der Waals contacts (3.3-3.6 ̊) necessary for $\pi$ dimer interactions. Yet this intramolecular interaction is obviously not favored in solution, as demonstrated by the lack of an absorption band in the NIR during spectroelectrochemical experiments.

These results may be related to the structures and more precisely to the relative arrangement of the two viologen planes. As observed in a reported bis-viologen ${ }^{29}$ or in verdazyl-based analogues, ${ }^{[30]}$ small variations of the geometry can greatly modify the nature of the ground state in pairs of organic radicals. In these flexible boxes, the length of the spacer and its parity modifies the parallel character of the two viologens. With a pentyl chain, the structure of $\mathbf{1}^{2(+)}$ is relatively rigid and imposes an angle between the planes of the two viologens. Although the antiferromagnetic OSS state is favored, intramolecular $\pi$-type interactions would be inefficient because of the molecule's ground state geometry. The longer 6 -membered chain of $2^{2(++)}$ allows greater distortions of the two viologen planes, in turn weakening the antiferromagnetic character and allowing several conformers. EPR and spectro-electrochemistry results indicate that in solution the two viologens act as unpaired radicals and form $\pi$-dimer interactions. In the longest 7 -membered chain of $3^{2(++)}$, the flexibility is even greater than in the shorter alkyl chains, allowing large distortions in which the viologen planes are no longer superimposed, such as in $3^{2(*)}(\mathrm{GA}, \mathrm{OSS})$ in Figure $6 f$. However, in solution this cyclophane must adopt the most stable ground state geometry in which the viologens are too far apart to form intramolecular interactions.

\section{Conclusion}

The use of an efficient strategy allowed us to circumvent the odd/even selection tendency observed in the synthesis of flexible bis-viologen cyclophanes and to prepare a cyclophane bearing alkyl linkers with six carbon atoms, thus completing this family of cyclophanes. Comparative electrochemistry studies of the varying ability of the three cyclophanes $1^{4}-3^{4+}$ to $\pi$-dimerize in solution upon reduction have been combined with EPR 
measurements and DFT calculations. The results suggest that odd/even effects not only impact the synthesis of viologen cyclophanes, but also influence the flexibility of the cyclic structures and consequently, their ability to contract and develop intramolecular electronic interactions. Thus, in the design of redox addressable hosts or molecular switches, odd and even effects have to be considered very carefully when choosing the connection between redox active species. Simple adjustments and geometric changes are suitable to adjust the response of the molecular device, for instance its spin state or its responsiveness.

\section{Experimental Section}

Synthetic generalities. Compound $\mathbf{4}\left(\mathrm{PF}_{6}\right)_{2}$ was synthesized by a reported method.[31] Reagents and solvents of reagent-grade were purchased and used without further purification. Column chromatography was performed with silica gel from Merck (Kieselgel 60; 40-63 $\mu \mathrm{m}$ ). Mass spectra analyses were performed by le Service de Spectrométrie de Masse de I'Institut de Chimie, Université de Strasbourg. Elemental analyses were performed by le Service d'Analyse Elementaire de l'Institut de Chimie, Université de Strasbourg. ${ }^{1} \mathrm{H}$ NMR spectra were recorded on Bruker Advance $400(400 \mathrm{MHz})$ or $500(500 \mathrm{MHz})$ spectrometers. Chemical shifts were determined by taking the solvent as a reference: $\mathrm{CD}_{3} \mathrm{CN}$ (1.94 ppm).

Compound $\mathbf{5}\left(\mathrm{PF}_{6}\right)_{4}$. Compound $\mathbf{4}\left(\mathrm{PF}_{6}\right)_{2}(2.0 \mathrm{~g}, 2.9 \mathrm{mmol})$ and 1-chloro2,4-dinitrobenzene $(5.90 \mathrm{~g}, 29.1 \mathrm{mmol})$ in $\mathrm{MeCN}(20 \mathrm{~mL})$ were stirred and refluxed under argon for 72 h. After cooling to r.t., the white precipitate was filtered, washed with $\mathrm{MeCN}$ and dissolved in a minimum of a mixture of water and acetone until complete dissolution. After addition of a saturated aqueous $\mathrm{KPF}_{6}$ solution $(15 \mathrm{~mL})$, the mixture was concentrated, filtered, washed with water and dried under vacuum to afford $5\left(\mathrm{PF}_{6}\right)_{4}$ as a white solid $(6.14 \mathrm{~g}, 4.7 \mathrm{mmol}, 81 \%)$. ${ }^{1} \mathrm{H}$ NMR $(500$ $\left.\mathrm{MHz}, \mathrm{CD}_{3} \mathrm{CN}, 25^{\circ} \mathrm{C}\right) \delta=1.51(\mathrm{~m}, 4 \mathrm{H}), 2.07(\mathrm{~m}, 4 \mathrm{H}), 4.66(\mathrm{t}, \mathrm{J}=7.6 \mathrm{~Hz}$, $4 \mathrm{H}), 8.16(\mathrm{~d}, \mathrm{~J}=8,6 \mathrm{~Hz}, 2 \mathrm{H}), 8.51(\mathrm{~d}, \mathrm{~J}=6.6 \mathrm{~Hz}, 4 \mathrm{H}), 8.63(\mathrm{~d}, \mathrm{~J}=6.8 \mathrm{~Hz}$, $4 \mathrm{H}), 8.86(\mathrm{dd}, \mathrm{J}=8.6 \mathrm{~Hz}, \mathrm{~J}=2.5 \mathrm{~Hz}, 2 \mathrm{H}), 8.97(\mathrm{~d}, \mathrm{~J}=6.6 \mathrm{~Hz}, 4 \mathrm{H}), 9.14$ $(\mathrm{d}, \mathrm{J}=6.8 \mathrm{~Hz}, 4 \mathrm{H}), 9.20$ (d, J = 2.5 Hz, 2H). ${ }^{13} \mathrm{C} \mathrm{NMR}\left(125 \mathrm{MHz}, \mathrm{CD}_{3} \mathrm{CN}\right.$, $\left.25{ }^{\circ} \mathrm{C}\right) \delta=25.8,31.5,62.9,123.2,128.3,128.5,131.4,132.5,138.9$, 144.2, 146.6, 147.6, 150.3, 151.0, 153.9. ESI HRMS: $\mathrm{m} / \mathrm{z}$ calc. $\left[\mathrm{C}_{38} \mathrm{H}_{34} \mathrm{~N}_{8} \mathrm{O}_{8} \mathrm{P}_{2} \mathrm{~F}_{12}\right]^{2+}=510.0886$, found $\left[\mathrm{M}^{4+} 2 \mathrm{PF}_{6}\right]=510.853 ; \mathrm{m} / \mathrm{z}$ calc. $\left[\mathrm{C}_{38} \mathrm{H}_{34} \mathrm{~N}_{8} \mathrm{O}_{8} \mathrm{PF}_{6}\right]^{3+}=291.7375$, found $\left[\mathrm{M}^{4+} \mathrm{PF}_{6}\right]=291.7358$ and $\mathrm{m} / \mathrm{z}$ calc $\left[\mathrm{C}_{38} \mathrm{H}_{34} \mathrm{~N}_{8} \mathrm{O}_{8}\right]^{4+}=182.5619$, found $\left[\mathrm{M}^{4+}\right]=182.5612$

Cyclophane 2( $\left.\mathrm{PF}_{6}\right)_{4} .1,6$-Hexanediamine $(0.546 \mathrm{~g}, 4.7 \mathrm{mmol})$ was added to a solution of compound $5\left(\mathrm{PF}_{6}\right)_{4} \quad(6.17 \mathrm{~g}, 4.7 \mathrm{mmol})$ and tetrathiafulvalene $(1.92 \mathrm{~g}, 9.4 \mathrm{mmol})$ in a mixture of $\mathrm{MeCN} / \mathrm{EtOH}(415 \mathrm{~mL}$ $(3 / 1))$. The green solution was stirred at r.t. under argon atmosphere for $12 \mathrm{~h}$. The solvent was evaporated and the crude product was dissolve in $\mathrm{MeCN}$. Saturated $\mathrm{Et}_{4} \mathrm{NCl}$ in $\mathrm{MeCN}$ was added until no further precipitation was observed. The resulting precipitate was filtered. The solid was dissolved in water and continuously extracted for 2 days with $\mathrm{CHCl}_{3}$. The aqueous phase became red. The aqueous phase was evaporated and purified by column chromatography $\left(\mathrm{SiO}_{2}\right.$, $\mathrm{MeCN} / \mathrm{MeOH} / \mathrm{H}_{2} \mathrm{O} /$ sat. $\left.\mathrm{NH}_{4} \mathrm{Cl}_{\text {aq }}(2 / 1 / 1 / 1)\right)$. The fractions containing the product were concentrated then dissolved in $\mathrm{H}_{2} \mathrm{O}$. A saturated aqueous solution of $\mathrm{KPF}_{6}$ was added until no further precipitation was observed. The resulting precipitate was filtered; the solid was washed with $\mathrm{H}_{2} \mathrm{O}$ and dried under vacuum to give compound $2\left(\mathrm{PF}_{6}\right)_{4}$ as a white solid $(0.69 \mathrm{~g}$, $0.65 \mathrm{mmol}, 14 \%) .{ }^{1} \mathrm{H}$ NMR $\left(500 \mathrm{MHz}, \mathrm{CD}_{3} \mathrm{CN}, 25^{\circ} \mathrm{C}\right) \delta=0.94(\mathrm{~m}, 8 \mathrm{H})$, $1.96(\mathrm{~m}, 8 \mathrm{H}), 4.60(\mathrm{t}, \mathrm{J}=5.8 \mathrm{~Hz}, 8 \mathrm{H}), 8.23(\mathrm{~d}, \mathrm{~J}=6.5 \mathrm{~Hz}, 8 \mathrm{H}), 8.79(\mathrm{~d}, \mathrm{~J}$
$=6.5 \mathrm{~Hz}, 8 \mathrm{H}) \cdot{ }^{13} \mathrm{C} \mathrm{NMR}\left(125 \mathrm{MHz}, \mathrm{CD}_{3} \mathrm{CN}, 25^{\circ} \mathrm{C}\right) \delta=25.6,30.9,63.0$, 127.8, 146.4, 150.5. ESI HRMS: calc. $\left[\mathrm{C}_{32} \mathrm{H}_{40} \mathrm{~N}_{4} \mathrm{PF}_{6}\right]^{3+}=208.4293$, found $\left[\mathrm{M}^{4+} \mathrm{PF}_{6}\right]=208.4321$ and $\mathrm{m} / \mathrm{z}$ calc. $\left[\mathrm{C}_{32} \mathrm{H}_{40} \mathrm{~N}_{4}\right]^{4+}=120.0808$, found $\left[\mathrm{M}^{4+}\right]$ $=120.0815$. E.A. (\%) calcd for $\mathrm{C}_{32} \mathrm{H}_{42} \mathrm{~N}_{4} \mathrm{P}_{4} \mathrm{~F}_{24}$ (1060.18): C 36.24, H 3.80, N 5.28, found: C 35.95, H 3.78, N 5.26.

Anion exchange: A saturated solution of $\mathrm{Et}_{4} \mathrm{NCl}$ in $\mathrm{MeCN}$ was added to a saturated solution of $\mathbf{1}\left(\mathrm{PF}_{6}\right)_{4}, \mathbf{2}\left(\mathrm{PF}_{6}\right)_{4}$ or $\mathbf{3}\left(\mathrm{PF}_{6}\right)_{4}$ in $\mathrm{MeCN}$ until no further precipitation was observed. After filtration, the solid was washed with $\mathrm{MeCN}$ and dried under vacuum to give compound $1 \mathrm{Cl}_{4}, 2 \mathrm{Cl}_{4}$ or $3 \mathrm{Cl}_{4}$, respectively, as a white solid.

X-ray crystallography. The crystals were placed in oil, and a single crystal was selected, mounted on a glass fiber and placed in a lowtemperature $\mathrm{N}_{2}$ stream. X-Ray diffraction data collection was carried out on a Bruker APEX II DUO Kappa-CCD diffractometer equipped with an Oxford Cryosystem liquid $\mathrm{N}_{2}$ device, using Mo-Ka radiation $(\lambda=0.71073$ $\AA$ ). The crystal-detector distance was $38 \mathrm{~mm}$. The cell parameters were determined (APEX2 software) ${ }^{[32]}$ from reflections taken from three sets of 12 frames, each at $10 \mathrm{~s}$ exposure. The structure was solved by direct methods using the program SHELXS-2013.[33] The refinement and all further calculations were carried out using SHELXL-2013. ${ }^{[33]}$ The $\mathrm{H}$ atoms were included in calculated positions and treated as riding atoms using SHELXL default parameters. The non-H atoms were refined anisotropically, using weighted full-matrix least-squares on F2. A semiempirical absorption correction was applied using SADABS in APEX2;[32] transmission factors: $T_{\min } T_{\max }=0.6353 / 0.7458$.

Electrochemistry: Materials. Pure water was used throughout. It was obtained by passing water through a Milli-RO4 unit and subsequently through a Millipore $\mathrm{Q}$ water purification set. $\mathrm{KCl}$ was commercial product from Prolabo (RP Normapur, purity $\geq 99.5 \%$ ).

Electrochemistry Measurements. Electrochemical measurements were carried out in $\mathrm{H}_{2} \mathrm{O}$ containing $0.1 \mathrm{M} \mathrm{KCl}$ in a classical three-electrode cell by cyclic voltammetry (CV) and rotating-disk voltammetry (RDV). The working electrode was a glassy carbon disk (GC, $3 \mathrm{~mm}$ in diameter), the auxiliary electrode a $\mathrm{Pt}$ wire, and the pseudo reference electrode a $\mathrm{Pt}$ wire. The cell was connected to an Autolab PGSTAT30 potentiostat (Eco Chemie, Holland) driven by a GPSE software running on a personal computer. All potentials are given vs. $\mathrm{Fc}^{+} / \mathrm{Fc}$ as well vs. $\mathrm{AgCl} / \mathrm{Ag}$ used as internal reference and are uncorrected from ohmic drop.

UV-Vis-NIR and IR Spectroelectrochemical Measurements. UV-VisNIR spectroelectrochemical experiments were performed with an optically transparent thin-layer electrochemical (OTTLE) cell (University of Reading UK, Hartl, F. $)^{[34]}$ equipped with a Pt mini-grid working electrode and $\mathrm{CaF}_{2}$ optical windows. IR spectroelectrochemical experiments were performed with an optically transparent thin-layer electrochemical (OTTLE) cell (University of Reading UK, Hartl, F.) ${ }^{[34]}$ equipped with a $\mathrm{Pt}$ mini-grid working electrode and $\mathrm{KBr}$ optical windows. UV-Vis-NIR spectroelectrochemical analyses have been carried out with a Zeiss MCS 601 UV-vis-NIR diode array spectrometer Spectrophotometric analyses of the films have been conducted using a $0.1 \mathrm{~mol} \mathrm{~L}^{-1}$ solution of $\mathrm{KCl}$ in $\mathrm{H}_{2} \mathrm{O}$. IR spectroelectrochemical analyses have been carried out with a Bruker Vertex 70 spectrometer at $1 \mathrm{~cm}^{-1}$ resolution (16 scans)

EPR experiments. EPR spectra were recorded with an ESP 300E spectrometer (Bruker) operating at $\mathrm{X}$-band and equipped with a standard TE102 rectangular cavity. Computer simulations of the EPR spectra were performed with the help of Winsim (NIEH Public Software) software. Radical cations were generated in situ by electrolysis in a flat, quartz 
microcell. Electrolyses were performed at controlled potential with a three electrode configuration under argon using a platinum wire as the working electrode, a platinum wire as the auxiliary electrode and a silver wire as the pseudo reference electrode. A dilute aqueous solution $(2 \mathrm{x}$ $\left.10^{-4} \mathrm{M}\right)$ of compounds $1 \mathrm{Cl}_{2}, 2 \mathrm{Cl}_{2}$ or $3 \mathrm{Cl}_{2}$ was prepared with $\mathrm{KCl}(0.1 \mathrm{M})$ as supporting electrolyte. A concentration of $4 \times 10^{-4} \mathrm{M}$ in water was used for the methylviologen reference.

Computational details. All calculations were performed with ADF 2013 package. The DFT level of calculations with B3LYP functional was used associated with a TZP basis set. Dispersion corrections with Grimme3 model were employed. PCM model of water was added. All the geometries were first optimized on the basis of the triplet states. Then starting from this geometry and wave function, the open shell singlet was obtained applying the spin-flip procedure. The geometry was then optimized again for this new wave function.

\section{Acknowledgements}

This work was supported by the Agence National de la Recherche (ANR-12-BS07-0014-01, PRIMO project), the Université de Strasbourg and the CNRS. We thank Vincent Robert for fruitful discussions about this research.

Keywords: viologen $\bullet$ cyclophane $\cdot$ pi-dimer $\bullet$ electrochemistry

[1] For reviews see: a) P. Ceroni, A. Credi, M. Venturi, Chem. Soc. Rev., 2014, 43, 4068-4083; b) E. R. Kay, Leign,c) V. Balzani, A. Credi, F. M. Raymo, J. F. Stoddart, Angew. Chem. Int. Ed. 2000, 39, 3348-3391; c) S. Erbas-Cakmak, D. A. Leigh, C. T. McTernan, A. L. Nussbaumer, Chem. Rev. 2015, 115, 10081-10206; d) E. R. Kay, D. A. Leigh, F. Zerbetto, Angew. Chem. Int. Ed. 2007, 46, 72-191; e) ed. J. F. Stoddart Acc. Chem. Res. 2000, 100, 406, special issue on Molecular Machines; f) K. Kinbara, T. Aida, Chem. Rev. 2005, 105, 1377-1400; g W. R. Browne, B. L. Feringa, Nat. Nanotechol. 2006, 1, 25-35; h) Y Shira, J.-F. Morin, T. Sasaki, J. M. Guerrero, J. M. Tour, Chem. Soc. Rev. 2006, 35, 1043-1055

[2] For selected examples: a) J. Chen, S. J. Wezenberg, B. L. Feringa, Chem. Commun. 2016, 52, 6765-6768; b) T. Lang, E. Graf, N. Kyritsakas, M. W. Hosseini, Chem. Eur. J. 2012, 18, 10419-10426; c) Y. Yamada, M. Okamoto, K. Furukawa, T. Kato, K. Tanaka, Angew. Chem. Int. Ed. 2012, 51, 709-713; d) F. Niess, V. Duplan, J.-P. Sauvage, J. Am. Chem. Soc. 2014, 136, 5876-5879; e) F. Niess, V. Duplan, C. S. Diercks, J.-P. Sauvage, Chem. Eur. J. 2015, 21, 14393-14400; f) S. $\varnothing$ Scottwell, J. D. Crowley, Chem. Commun. 2016, 52, 2451-2464; g) K Miwa, Y. Furusho, E. Yashima, Nat. Chem. 2010, 2, 444-449; h) N Zigon, M. W. Hosseini, Chem. Commun. 2015, 51, 12486-12489.

[3] a) J. W. Lee, I. Hwang, W. S. Jeon, Y. H. Ko, S. Sakamoto, K. Yamaguchi, K. Kim, Chem. Asian J. 2008, 3, 1277-1283; b) J. Sun, Y. Wu, Y. Wang, Z. Liu, C. Cheng, K. J. Hartlieb, M. R. Wasielewski, J. F. Stoddart, J. Am. Chem. Soc. 2015, 137, 13484-13487.

[4] a) A. Iordache, M. Oltean, A. Milet, F. Thomas, B. Baptiste, E. SaintAman, C. Bucher, J. Am. Chem. Soc., 2012, 134, 2653-2671; b) A Takai, T. Yasuda, T. Ishizuka, T. Kojima, M. Takeuchi, Angew. Chem. Int. Ed. Engl. 2013, 52, 9167-9171.

[5] For selected examples see: a) A. Iordache, M. Retegan, F. Thomas, G. Royal, E. Saint-Aman, C. Bucher, Chem. Eur. J. 2012, 18, 7648-7653; b) C. Kahlfuss, A. Milet, J. Wytko, J. Weiss, E. Saint-Aman, C. Bucher Org. Lett. 2015, 17, 4058-4061; c) M. H. Düker, H. Schäfer, M. Zeller, V.
A. Azov, J. Org. Chem. 2013, 78, 4905-4912; d) C. Bejger, C. M. Davis J. S. Park, V. M. Lynch, J. B. Love, J. L. Sessler, Org. Lett. 2011, 13 4902-4905; e) V. J. Chebny, R. Shukla, S. V. Lindeman, R. Rathore, Org. Lett. 2009, 11, 1939-1942; f) J. Lyskawa, M. Sallé, J. Y. Balandier, F. Le Derf, E. Levillain, M. Allain, P. Viel, S. Palacin, Chem. Commun. 2006, 2233-2235; g) G. Pognon, C. Boudon, K. J. Schenk, M. Bonin, B. Bach, J. Weiss J. Am. Chem. Soc. 2006, 128, 3488-3489; h) M. Hardouin-Lerouge, P. Hudhomme, M. Sallé, Chem. Soc. Rev. 2011, 40, 30-43; i) J. Leblond, A. Petitjean, ChemPhysChem, 2011, 12, 1043 1051.

[6] a) R. A. Bissell, E. Córdova, A. E. Kaifer, J. F. Stoddert, Nature, 1994, 369, 133-137; b) J.-P. Collin, P. Gavĩna and J.-P. Sauvage, New J. Chem. 1997, 21, 525-528.

[7] For several reviews, see: a) S. Durot, F. Reviriego, J.-P. Sauvage, Dalton Trans. 2010, 39, 10557-10570; b) M. Xue, Y. Yang, X. Chi, X. Yan, F. Huang, Chem. Rev. 2015, 115, 7398-7501; c) J. F. Stoddart, Chem. Rev. 2009, 38, 1802-1820.

[8] For recent reviews, see: a) F. Niess, V. Duplan, J.-P. Sauvage, Chem Lett. 2014, 43, 964-974; b) C. J. Bruns, J. F. Stoddart, Acc. Chem. Res. 2014, 47, 2186-2199;

[9] a) K. Takimiya, Y. Aso, F. Ogura, T. Otsubo, Chem. Lett. 1995, 735736; b) M. Brøndsted Nielsen, N. Thorup, J. Becher, J. Chem. Soc. Perkin Trans. 1, 1998, 1305-1308; c) H. Spanggaard, J. Prehn, M. B. Nielsen, E. Levillain, M. Allain, J. Becher, J. Am. Chem. Soc. 2000, 122, 9486-9494; d) K. Takimiya, A. Oharuda, Y. Aso, F. Ogura, T. Otsubo Chem. Mater. 2000, 12, 2196-2204; e) K. Takimiya, N. Thorup, J. Becher, Chem. Eur. J. 2000, 6, 1947-1954; f) M. Iyoda, M. Hasegawa Y. Miyake, Chem. Rev. 2004, 104, 5085-5113; g) J. O. Jeppesen, M. Brøndsted Nielsen, J. Becher, Chem. Rev. 2004, 104, 5115-5131; h) W. Wang, S. M. Dyar, D. Cao, A. C. Fehrenbach, N. Horwitz, M. T. Colvin, R. Carmieli, C. L. Stern, S. K. Day, M. R. Wasielewski, J. F. Stoddart, J Am. Chem. Soc. 2012, 134, 19136-19145; i) K.-i. Nakamura, Y. Okada, T. Shirahata, Y. Misaki, Chem. Lett. 2014, 43, 708-710.

[10] J. Casado, K. Takimiya, T. Otsubo, F. J. Ramírez, J. J. Quirante, R Ponce Ortiz, S. R. González, M. Moreno Oliva, J. T. López Navarrete, J. Am. Chem. Soc. 2008, 130, 14028-14029.

[11] D. F. Schlosser, M. Moos, C. Lambert, F. Würthner, Adv. Mater. 2013 25, 410-414.

[12] E. M. Kosower, J. L. Cotter, J. Am. Chem. Soc. 1964, 86, 5524-5527

[13] a) J. W. Lee, Hwang, W. S. Jeon, Y. H. Ko, S. Sakamoto, K. Yamaguchi, K. Kim, Chem.-Asian J. 2008, 3, 1277-1283; b) T. Zhang, S. Sun, F. Liu, J. Fan, Y. Pang, L. Sun X. Peng, Phys. Chem. Chem. Phys. 2009, 11, 11134-11139; c) J. W. Lee, S. Samal, N. Selvapalam H-J. Kim, K. Kim, Acc. Chem. Res. 2003, 36, 621-630.

[14 ] a) S. J. Atherton, S. J.; Tsukahara, K. T.; Wilkins, R. C. J. Am. Chem. Soc. 1986, 108, 3380-3385; b) Furue, M.; Nozukura, S. I. Bull. Chem. Soc. Jpn. 1982, 55, 513-516; c) Deronzier, A.; Galland, B.; Vieira, M. Nouv. J. Chim. 1982, 97-100; d) Furue, M.; Nozukura, S. I. Chem. Lett. 1980, 9, 821-824.; e) Hirayama, F. J. Chem. Phys. 1965, 42, 3163

[15] (a) B. Odell, M. V. Reddington, A. M. Z. Slawin, N. Spencer, J. F. Stoddart, D. J. Williams, Angew. Chem., Int. Ed. Engl. 1988, 27, 1547-1550; b) J. F. Stoddart, H. M. Colquhoun, Tetrahedron, 2008, 64 8231-8263

[16] J. C. Barnes, A. C. Fahrenbach, D. Cao, S. M. Dyar, M. Frasconi, M. A Giesener, D. Benítez, E. Tkatchouk, O. Chernyashevskyy, W. H. Shin, H. Li, S. Sampath, C. L. Stern, A. A. Sarjeant, K. J. Hartlieb, Z. Liu, R. Carmieli, Y. Y. Botros, J. W. Choi, A. M. Z. Slawin, J. B. Ketterson, M. R. Wasielewski, W. A. Goddard III, J. F. Stoddart, Science, 2013, 339 429-433.

[17] a) A. Trabolsi, N. Khashab, A. C. Fahrenbach, D. C. Friedman, M. T. Colvin, K. K. Cotí, D. Benítez, E. Tkatchouk, J.-C. Olsen, M. E. Belowich, R. Carmielli, H. A. Khatib, W. A. Goddard III, M. R. Wasielewski, J. F. Stoddart, Nature Chem. 2010, 2, 42-49; b) A. C. 
Fahrenbach, J. C. Barnes, D. A. Lanfranchi, H. Li, A. Coskun, J. J. Gassensmith, Z. Liu, D. Benítez, A. Trabolsi, W. A. Goddard III; M. Elhabiri, J. F. Stoddart, J. Am. Chem. Soc., 2012, 134, 3061-3072;

[18] M. Berville, L. Karmazin, J. A. Wytko, J. Weiss, Chem. Commun. 2015 51, 15772-15775.

[19] T. Zincke, G. Heuser, W. Möller, Liebigs Ann. 1904, 333, 296-345.

[20] The Zincke reaction was previously used in the cyclization step of several viologen-containing macrocycles: H. M. Colquhoun, B. W Greenland, Z. Zhu, J. S. Shaw, C. J. Cardin, S. Burattini, J. M. Elliott, S. Basu, T. B. Gasa, J. F. Stoddart, Org. Lett. 2009, 11, 5238-5241.

[21] J. B. Wittenberg, P. Y. Zavaliji, L. Issacs, Angew. Chem. Int. Ed. 2013, 52, 87-94.

[22] For the titration, the initial concentration of $\mathbf{5}\left(\mathrm{PF}_{6}\right)_{4}$ was nearly identical to that in the cyclization reaction. The binding constant is $0.9 \pm 0.4 \mathrm{M}^{-1}$ in $\mathrm{MeCN} / \mathrm{EtOH}(3 / 1)$

[23] a) S. Kunugi, T. Okubo, N. Ise, J. Am. Chem. Soc. 1976, 98, 2282 2287; b) E. N. Marvell, G. Caple, I. Shahidi, J. Am. Chem. Soc. 1970 92, 5641-5645.

[24] a) F. B. L. Cougnon, N. Ponnuswamy, N. A. Jenkins, G. D. Pantoş, J. K. M. Sanders, J. Am. Chem. Soc. 2012, 134, 19129-19135; b) A. TorresHuerta, H. Höpfl, H. Tlahuext, I. F. Hernández-Ahuactzi, M. Sánchez, R Reyes-Martínez, D. Morales-Morales, Eur. J. Inorg. Chem. 2013, 61-69 C) K. E. Jelfs, E. G. B. Eden, J. L. Culshaw, S. Shakespeare, E. O. Pyzer-Knapp, H. P. G. Thompson, J. Bacsa, G. M. Day, D. J. Adams, A I. Copper, J. Am. Chem. Soc. 2013, 135, 9307-9310.

[25] CCDC-1051149 contain(s) the supplementary crystallographic data for this paper. These data can be obtained free of charge from The Cambridge Crystallographic Data Centre via www.ccdc.cam.ac.uk/data\%5Frequest/cif. Crystallization solvents: MeCN/diisopropylether; Crystal size: $0.30 \times 0.22 \times 0.15 \mathrm{~mm}$ Identification: $\left(\mathrm{C}_{32} \mathrm{H}_{40} \mathrm{~N}_{4}\right)\left(\mathrm{PF}_{6}\right)_{4}$; formula: $\mathrm{C}_{32} \mathrm{H}_{40} \mathrm{~F}_{24} \mathrm{~N}_{4} \mathrm{P}_{4}$; Formula Weight: $1060.56 \mathrm{~g} / \mathrm{mol}$; Color: Colorless; Crystal system: orthorhombic
Space group: Pnna, Unit cell dimensions ( $\AA$ and deg): $a=15.0492(7)$ a $=90 ; b=25.0265(11) \beta=90 ; c=11.7886(6) \gamma=90 ;$ Volume: $4439.9(4)$ $\AA^{3}, \mathrm{Z}=4$; Density: $1.587 \mathrm{mg} / \mathrm{m}^{3}$, Temperature: $173(2) \mathrm{K}$; Absorption coefficient: $0.302 \mathrm{~mm}^{-1}$; 20max: 58.06 deg.; Reflections collected: 26441; Reflections unique: 5915 ; Goodness of fit: $1.049 ; R_{f}=0.0777$ $w R_{f}=0.2348$

[26] a) M. Itoh, E. M. Kosower, J. Am. Chem. Soc. 1967, 89, 3653-3656; b) M. Itoh, E. M. Kosower, J. Am. Chem. Soc. 1968, 90, 1843-1849.

[27] a) J. M. Lü, S. V. Rosakha, J. K. Kochi, J. Am. Chem. Soc. 2003, 125 12161-12171; b) Y. Jung, M. Head-Gordon, J. Phys. Chem. Chem. Phys. 2004, 6, 2008-2011; c) J. J. Novoa, P. La Fuente, R. E. Del Sesto, J. S. Miller, Angew. Chem. Int. Ed., 2001, 40, 2540-2545; c) Y. H. Tian, M. Kertesz, J. Phys. Chem. A, 2011, 115, 13942-13949.

[28] J. C. Evans, C. R. Morris, C. C. Rowland, Tetrahedron, 1987, 43, 5329 5334

[29] A. lordache, R. Kannappan, E. Métay, M.-C. Duclos, S. Pellet-Rostaing M. Lemaire, A. Milet, E. Saint-Aman, C. Bucher, Org. Biomol. Chem. 2013, 11, 4383-4389.

[30] a) M. Vérot, N. Bréfuel, J. Pécaut, C. Train, V. Robert, Chem. Asian J. 2012, 7, 380-386; b) J.-B. Rota, B. Le Guennic, V. Robert, Inorg. Chem. 2010, 49, 1230-1237.

[31] Adapted from: A. lordache, M. Retegan, F. Thomas, G. Royal, E. SaintAman, C. Bucher, Chem. Eur. J., 2012, 18, 7648-7653.

[32] "M86-E01078 APEX2 User Manual", Bruker AXS Inc., Madison, USA 2006

[33] G. M. Sheldrick, Acta Cryst. 2008, A64, 112-122.

[34] M. Krejčík, M. Danĕk, F. J. Hartl, J. Electroanal. Chem. 1991, 317, 179-187. 
Entry for the Table of Contents (Please choose one layout)

Layout 1:

\section{FULL PAPER}

Text for Table of Contents

Layout 2:

\section{FULL PAPER}

Mathilde Berville, Corinne Boudon, Laurent Ruhlmann, Sylvie Choua, Maxime Bernard, Corinne Bailly, Jennifer Wytko, * Jean Weiss, ${ }^{*}$ Saioa Cobo and Eric Saint-Aman

Page No. - Page No.

Flexible viologen cyclophanes: odd/even effects on $\pi$-dimerization
((Insert TOC Graphic here; max. width: $11.5 \mathrm{~cm}$; max. height: $2.5 \mathrm{~cm})$ )
Author(s), Corresponding Author(s)*

Page No. - Page No.

Title

Text for Table of Contents 